\title{
ENVIRONMENTAL VARIABLES AND ECOLOGICAL DISTRIBUTION OF ICHTHYOFAUNA ASSEMBLAGES IN THE CALABAR RIVER, NIGERIA: PRESENT AND FUTURE PROSPECTS
}

\author{
Andem Bassey Andem*, Sunday Ben Ekanem, Esien Ene Oku \\ University of Calabar, Department of Zoology and Environmental Biology, Cross River State, Nigeria \\ *Corresponding Author, Email: a.b.andem@unical.edu.ng
}

\section{ARTICLE INFO}

Received: 1 July 2016

Received in revised form: 1 September 2016

Accepted: 3 September 2016

Available online: 4 October 2016

\section{Keywords:}

Ecological distribution

Ichthyofauna

Biotic indices

Pollution

\begin{abstract}
Studies on environmental variables and ecological distribution of ichthyofauna assemblages were conducted in the Calabar River. Surface water and ichthyofauna were sampled in order to provide baseline or reference data on the Calabar River at present as regard its future prospects. Seasonal variation shows significant differences in surface water temperature, $\mathrm{pH}, \mathrm{DO}, \mathrm{BOD}$, conductivity, TDS and TSS between sampling stations and insignificant differences in heavy metals such as cadmium, chromium, iron and copper between sampling stations. Twenty six species of fish fauna were identified belonging to twenty two families. Mugilidae, Clariidae, Cichlidae, Gobiidae and Sciaenidae were the most abundant for both wet and dry season, while Clupeidae, Bathyclupeidae, Carangidae and Sphyraenidae were low in the wet season but high in the dry season. Chromium, copper, surface water temperature, DO correlate significantly with the presence of E. fimbriata, B. soporator, M. sebae, C. gariepinus, $M$. loennbergii, $C$. guentheri and $P$. babarus. The overall values of biotic diversity indices ranged from 0.0504-0.0745 for Simpson's Index, 2.7703.095 for Shannon Index, 2.821-3.105 for Margalef's Index and 0.86060.9498 for equitability. However, the presence of certain fish fauna in polluted and non-polluted parts of the river indicates that they could be used as potential bioindicators in assessment and biomonitoring of the river. The methods used in identifying fish diversity proved their applicability for future studies.
\end{abstract}

How to Cite

Andem, A. B., Ekanem, S. B., Oku, E. E. (2016): Environmental variables and ecological distribution of ichthyofauna assemblages in the southeastern coastal region of the Calabar River, Nigeria. Croatian Journal of Fisheries, 74, 159-171. DOI: 10.1515/cjf-2016-0024.

\section{INTRODUCTION}

Freshwater ecosystems in tropical Africa are rich in fauna and flora species and they are very complex, especially species. In Nigeria, these fishes are widely spread all over the fresh water bodies; this is based on their morphology and life history, and attributed to their different features and habitats in which they are embedded (Mims et al., 2010). The ecology of rivers in tropical Africa is dominated by flow seasonality 
with profound consequences for fishes and zoobenthos during the wet season (Dudgeon, 2000). Thus, fluctuations and changes in discharge patterns affect the abundance, species composition and viability of living aquatic resources resident in the river. Also, along the river gradient, the variations in geo-morphological characteristics of the river as well as environmental variables (both biotic and abiotic) are the major factors that govern fish communities both in terms of species richness and distribution of individual species (Orrego et al., 2009; Alexandre et al., 2010; Kimmel and Argent, 2010).

Moreover, different aquatic environments favour particular traits of fish species making them develop different strategies that enable different fish species to cope with a range of ecological challenges (Mims et al., 2010). However, any river system under normal conditions is characterized by constant increase of fish species (Orrego et al., 2009). In a fluvial ecosystem, species composition is influenced by some parameters such as altitude, gradient, current velocity and temperature. However, the downstream, functional structure of the river changes as a result of some physical factors such as flow regime, temperature, food availability and river morphological conditions (Orrego et al., 2009). Generally, fishes show high adaptability to their habitat environment, whereas their morphological and ecological characteristics change correspondingly ( $\mathrm{He}$ et al., 2010). The range of distribution of fish species from the source (upstream) to the discharge point (downstream) is determined by the ecological requirements of each fish species (Ferreira and Petrere, 2009). Most fish in the river system cannot live their whole lives in one habitat, especially when requirements for reproduction and feeding at different life stages cannot be met in the same place; fishes therefore have to move between places to survive (Baran and Jutagate, 2010). Different classes of fish in Nigeria can complete their life cycle only if they can gain access to different riverine environment. There are two types of riverine environment which different fishes spawn on; obligatory species spawn only in the river corridor, while non-obligatory or facultative riverine species realize their life history strategy in both lotic and lenthic waters (Penczak, 2002).

Ita (1993) in his study reported that there are about 511 species of fish in Nigerian water bodies of which about $34 \%$ are restricted to Exclusive Economic Zone (EEZ), while approximately $44 \%$ are freshwater fishes inhabiting waters of very low salinities (below 1 part per thousand (ppt) or conductivity of $1000 \mu \mathrm{S} / \mathrm{cm}$ ). The presence of Potamotrygeon garouensis in the waters of northern Nigeria (Reed et al., 2000; Obasohan and Oronsaye, 2006) and the River Ase in Delta State of Nigeria (Idodo-Umeh, 1987) is of scientific interest because Potamotrygeon garouensis is a ray of the family Dasyatidae. These species which occur in both brackish and freshwaters are unique and so require protection. The majority of Carangidae were marine water fish, while Characidae were mostly fresh water fish, except the two species of Myletes, $M$. guile and $M$. nurse, which are brackish (Obasohan and Oronsaye, 2006). Among Carangidae, only Trachinotus goreensis, a marine species, has been reported in these freshwaters (Kusemiju and Olaniyan, 1997) and Oguta Lake (Nwadiaro, 1984). These species appear restricted in distribution and therefore need to be protected. Mudskipper Periophthalmus sp. (family Periopthalmidae) is a fish of great biological and evolutionary significance. The continued existence of this fish is seriously threatened by pollution arising from oil spills and reclamation exercises, especially in the mangroves and Lagos Lagoon

Table 1. List of endangered freshwater fishes in Nigeria

\begin{tabular}{|c|c|c|}
\hline Family & Species & Distribution \\
\hline Albulidae & Albula vulpes & Warri River \\
\hline Amphillidae & Phractura clauseri & Ogun River \\
\hline Carangidae & $\begin{array}{l}\text { Trachinotus } \\
\text { goreensis }\end{array}$ & Niger/Benue \\
\hline Centropomidae & Lates niloticus & Widespread \\
\hline Cromerridae & Cromeria nilotica & Niger/Benue \\
\hline Gymnaichiidae & $\begin{array}{l}\text { Gymnanchus } \\
\text { niloticus }\end{array}$ & Widespread \\
\hline Hepsetidae & Hepsetus odoe & Widespread \\
\hline Lepidosireniidae & $\begin{array}{l}\text { Protopterus } \\
\text { annectens }\end{array}$ & Fair Distribution \\
\hline Lutjanidae & Lutjanus spp & Cross River \\
\hline Mastacembelidae & $\begin{array}{l}\text { Mmastacembelus } \\
\text { loennbergii }\end{array}$ & Fair Distribution \\
\hline Malapteruriidae & $\begin{array}{l}\text { Mmalapterurus } \\
\text { electricus }\end{array}$ & Widespread \\
\hline Nanidae & $\begin{array}{l}\text { Polycentropsis } \\
\text { abbreviate }\end{array}$ & Fair Distribution \\
\hline Ophiocephalidae & $\begin{array}{l}\text { Paraophiocephalus } \\
\text { africana }\end{array}$ & Oguta Lake \\
\hline Osteoglossidae & Heterotis niloticus & Widespread \\
\hline Pantodoltidae & Pabtodon putcholzi & Fair Distribution \\
\hline Phracholaemidae & $\begin{array}{l}\text { Phracholeamus } \\
\text { ansorgei }\end{array}$ & Fair Distribution \\
\hline Synbranchidae & Synbranchus afer & Ethiope River \\
\hline Trigonidae & Trigon margrarita & Epe Lagoon \\
\hline \multicolumn{3}{|c|}{ Estuarine and marine migratory species } \\
\hline Pristidae & Pristis perrottetis & Niger/Benue \\
\hline Trigonidae & $\begin{array}{l}\text { Potamotryon } \\
\text { garouensis }\end{array}$ & Niger/Benue \\
\hline Monodactylidae & Monodactylus sebae & Niger/Benue \\
\hline
\end{tabular}


beaches. Welman (2003) identified 181 fish species from the major river systems in Nigeria which included estuarine and marine fishes present in the rivers. Banks et al. (1965) identified and described about 139 fish species in the River Niger within the proposed Kainji Reservoir Basin. Reed et al. (2000) investigated and reported about 160 fish species in the northern region of Nigeria. Many fish species have been identified in Kainji Lake and other freshwater bodies leading to the description and identification of fish species in Nigeria (Ita, 1978). One of the recent investigations into the fish diversity of the major rivers of Nigeria (Ita, 1993; Obasohan and Oronsaye, 2006) recorded 239 fish species. There are at least 18 freshwater species in Nigeria which are endangered (Table 1). A drastic decline has recently been observed among larger species such as Gymnarchus niloticus. Lates niloticus, Heterobranchus bidorsalis and Protopterus annectus (Ita, 1993; Obasohan and Oronsaye, 2006).

The importance of this study is to complement available information in the baseline data and help in the exploitation of fishery, execution of fisheries policies and programmes, especially in the artisanal sector. This will ensure effective management as well as biodiversity conservation. This study was aimed at evaluating some environmental variables and ecological distribution, diversity and abundance of ichthyofauna assemblages of the Calabar River in Nigeria.

\section{MATERIALS AND METHODS}

\section{Description of study area}

The Calabar River flows from the northern part of the city of Calabar joining the southern at about $8 \mathrm{~km}$. This river forms a natural harbour deep enough for vessels with a draft of $6 \mathrm{~m}$. The river drains from the part of Oban hills in the Cross River National Park (Cross River National Park, 2010 ) with the longitude of $8^{\circ} 18^{\prime} \mathrm{E}$ and latitude of $4^{\circ} 58^{\prime} 3 \mathrm{~N}$ (Fig. 1.) (Andem et al., 2013). The basin of the river is about $43 \mathrm{~km}$ wide and $62 \mathrm{~km}$ long, with an area of $1,514 \mathrm{~km}^{2}$ (Eze and Effiong, 2010). The region has a wet season between April and October with about $80 \%$ of the annual rainfall, with the peak of rainfall between June and September. The river has an annual rainfall average of about $1,830 \mathrm{~mm}$, average temperature range from $24^{\circ} \mathrm{C}\left(75^{\circ} \mathrm{F}\right)$ in August to $30^{\circ} \mathrm{C}\left(86^{\circ} \mathrm{F}\right)$ in February. Relative humidity is high and it ranges between $80 \%$ and $100 \%$ (Eze and Effiong, 2010). The river basin has about 223 streams with a total length of $516 \mathrm{~km}$; this is a small number given the size of the basin. The drainage system in Calabar is poor so the basin is subjected to gully erosion, flooding and landslides; in fact, a 2010 study said that flood had increased in recent years (Eze and Effiong, 2010).

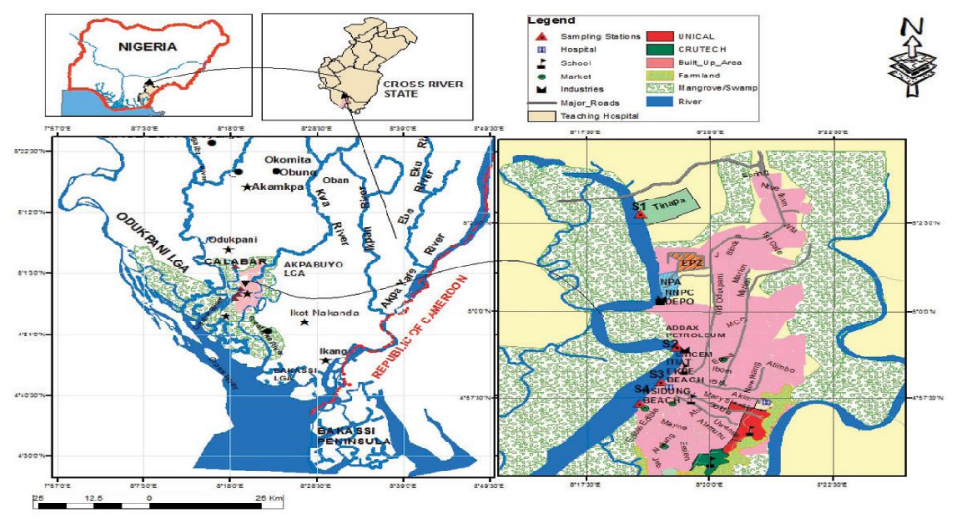

Fig 1. Map of study area showing different sampling stations

\section{Sampling stations}

Four stations (1-4) were chosen along the shoreline of the river. Co-ordinates of each station were digitized using Arc Geographic Information System (GIS) software.

\section{Station One (S1)}

It is coastal water which flows behind Africa's first ever free trade zone which is also a tourist destination with a serene environment; it is an upstream station which serves as a control point. This station is assumed to be unpolluted since the wastes which flow into the river from this point are minimal. The water channels are clean, very little activity occurs at the river banks and fishing activities are restricted for security reasons. The station is located at Tinapa Resort Beach between latitude: N 5002' 820", longitude: E $8^{\circ} 19^{\prime}$ 16 " at 23 feet altitude.

\section{Station Two (S2)}

Station 2 is the first discharge point; it receives effluents from shipping activities, off-loading of finished petroleum product from ship to pipelines; fishing activity is minimal and some of the industrial wastes are also drained into the river. This station is located at Addax Petroleum Company between latitude: $N 4^{\circ} 58^{\prime} 988^{\prime \prime}$, longitude: E $8^{\circ} 16^{\prime} 872^{\prime \prime}$ at 24 feet altitude.

\section{Station Three (S3)}

This station is the second discharge point; it consists of linear settlement across the river bank where fishing activities predominate; ships and boats also anchor along this beach. The Station is located at Itiat Ekpe Beach between latitude: N $4^{\circ} 32^{\prime} 124^{\prime \prime}$, longitude: E $8^{\circ} 16^{\prime} 872$ " at 42 feet altitude. 


\section{Station Four (S4)}

This station is a commercial station with a large market located at the bank of the river. Anthropogenic wastes from this station also empty into the river. This is a landing site for fishermen and a big fish market. This station is located at Nsidung Beach between latitude: N 4 57' 326”, longitude: E $8^{\circ} 18^{\prime} 557^{\prime \prime}$ at 26 feet altitude.

\section{Physico-chemical parameters}

Samples were collected monthly between January and December 2013 at four different stations, usually between 7:00 a.m and 10:00 a.m. The physico-chemical parameters investigated in each case were surface water temperature, $\mathrm{pH}$, dissolved oxygen (DO), biochemical oxygen demand (BOD), conductivity, total dissolved solids (TDS), total suspended solids (TSS) and heavy metals, all from surface waters. In each sampling station, surface water temperature of the river was measured with a mercuryin-glass thermometer which was inserted into the water at a depth of $2 \mathrm{~cm}$ from the surface for 3 minutes. The readings were expressed in degrees Celsius $\left({ }^{\circ} \mathrm{C}\right)$. The $\mathrm{pH}$ was measured in situ using pocket $\mathrm{pH}$ meter ( $\mathrm{pH} 1$ model). The probe of the meter was dipped into the water sample and the $\mathrm{pH}$ read as recommended by APHA, AWWA, WEF (1995). Dissolved oxygen was measured in situ with DO meter (Model DO-5509) and the water sample was taken to the Postgraduate Laboratory, Department of Zoology and Environmental Biology and incubated for five days at $20^{\circ} \mathrm{C}$; after five days the reading was taken. The first day $\mathrm{DO}$ minus the fifth day $\mathrm{DO}\left(\mathrm{DO}_{1}-\mathrm{DO}_{5}\right)$ gave $\mathrm{BOD}$. In the laboratory, conductivity, TDS and TSS were measured using Hannah Instrument (Bench meter 211 model). A different probe of the meter for each parameter was immersed in the water samples collected; parameters such as conductivity, TDS and TSS were read off as recommended by APHA, AWWA, WEF (1995). Heavy metals were determined by digesting $250 \mathrm{ml}$ of water samples with $10 \mathrm{ml}$ analytical grade nitric acid to acidify it; the solution was evaporated on a crucible to approximately $25 \mathrm{ml}$ then filtered into a standard flask and diluted with distilled water (Farombi et al., 2007). The mixture was gently heated in a water bath until the acid became bleached. The digested water samples were analyzed for lead $(\mathrm{Pb})$, copper $(\mathrm{Cu})$, iron (Fe), chromium ( $\mathrm{Cr}$ ) and cadmium (Cd) using Perkin Elmer's AAnalyst 200 version 6.0 Atomic Absorption Spectrometer (AAS).

\section{Fish sampling procedure}

The gears and methods used were in accordance with the recommendation of Gullard (1980); reliable sampling involves a combination of two or more gears. In each sampling period, fishing was carried out during high tide and low tide, both during the day and night. Sampling was done once a month for twelve months (January-December 2013). The gears consisted of cast net (10-15 mm mesh size), drift net ( $5 \mathrm{~mm}$ mesh size), gill net ( $5 \mathrm{~mm}$ mesh size), local traps, hook and line. A uniform fishing effort of 2 fishermen in each sampling station for six hours per day was maintained throughout the study period. Fish were collected and put into an iced cooler and transported to the laboratory where they were identified and presenved in $10 \%$ formalin for further examination. The fishes were identified using the following key guides: FAO, (2001), Idoho-Umeh (2003) and Adesulu and Sydenham (2007); after identification each fish species was counted and recorded accordingly.

\section{Statistical analysis}

Data obtained were subjected to descriptive statistics for mean, standard error and range values. Analysis of variance (ANOVA) was used to test the significant difference between seasonal variations of physico-chemical parameters and fish fauna of the Calabar River. Effects with a probability of $p<0.05$ were considered significant. Biotic indices such as Simpson's index, Margalefs index, Shannon-Wiener index were used to estimate species dominance, abundance, richness and evenness using PAST (Paleontological Statistics) software. Microsoft Excel 2013 (Microsoft Corporation 1985-2013) was used for graphical illustrations. Two-tailed correlation coefficient $(r)$ was used to determine the relationships existing between the physico-chemical parameters of water and abundance of fish fauna of the Calabar River (Ogbeibu, 2005).

\section{RESULTS}

\section{Physico-chemical parameters}

Summary of the data obtained on mean variation, range and F-value of physico-chemical parameters studied between January and December 2013 is presented in Table 2. Seasonal mean, standard error values and analysis of variance on physico-chemical parameters measured in the Calabar River are shown in Table 3.

During the study period, surface water temperature ranged from 25.92 to $27.92^{\circ} \mathrm{C}$ with the mean value of $26.97 \pm 0.84^{\circ} \mathrm{C}$ (Table 2 ). Within four sampling stations, spatial variations of surface water temperature showed insignificant difference at $p>0.05$ (Table 2). Mean surface water temperatures obtained in the wet season and dry season were $27.33 \pm 1.11^{\circ} \mathrm{C}$ and $26.71 \pm 0.70^{\circ} \mathrm{C}$ (Table 3), respectively. Seasonal variation between the wet and dry 
Table 2. Mean, range and F-value of physico-chemical parameters measured in the Calabar River

\begin{tabular}{|c|c|c|c|c|c|c|}
\hline $\begin{array}{l}\text { Physico-chemical } \\
\text { parameters }\end{array}$ & Range & Mean \pm S.E & F-value & P-Probability & Inferences & $\begin{array}{c}\text { NESREA } \\
\text { Permissible } \\
\text { limit }\end{array}$ \\
\hline Water Temperature $\left({ }^{\circ} \mathrm{C}\right)$ & $25.92-27.92$ & $26.97 \pm 0.84$ & 4.92 & $P>0.05$ (NS) & $\mathrm{H}_{0}$ accepted & $20-40^{\circ} \mathrm{C}$ \\
\hline $\mathrm{pH}$ & $7.20-7.69$ & $7.44 \pm 0.25$ & 0.015 & $P>0.05$ (NS) & $\mathrm{H}_{0}$ accepted & $6.0-9.0$ \\
\hline Dissolved Oxygen $(\mathrm{mg} / \mathrm{L})$ & $3.07-3.79$ & $3.35 \pm 0.33$ & 23.90 & $P>0.05$ (NS) & $\mathrm{H}_{0}$ accepted & 5.0 \\
\hline $\begin{array}{l}\text { Biological Oxygen Demand } \\
(\mathrm{mg} / \mathrm{L})\end{array}$ & $1.53-1.99$ & $1.82 \pm 0.21$ & 1.56 & $\mathrm{P}>0.05$ (NS) & $\mathrm{H}_{0}$ accepted & 50 \\
\hline Conductivity $(\mu \mathrm{S} / \mathrm{cm})$ & $237.14-290.67$ & $254.31 \pm 24.56$ & 12.92 & $\mathrm{P}<0.05(\mathrm{~S})$ & $\mathrm{H}_{0}$ rejected & $50-600$ \\
\hline Total Dissolved Solid (mg/L) & $414.63-700.14$ & $528.63 \pm 124.69$ & 2.16 & $P<0.05(S)$ & $\mathrm{H}_{0}$ rejected & 500 \\
\hline Total Suspended Solid (mg/L) & $1093.77-1376.06$ & $1205.35 \pm 125.57$ & 2.35 & $\mathrm{P}<0.05(\mathrm{~S})$ & $\mathrm{H}_{0}$ rejected & $>10$ \\
\hline Lead $(\mathrm{mg} / \mathrm{L})$ & $0.00-0.01$ & $0.01 \pm 0.001$ & 2.59 & $\mathrm{P}<0.05(\mathrm{~S})$ & $\mathrm{H}_{0}$ rejected & 0.05 \\
\hline Cadmium (mg/L) & $0.00-0.02$ & $0.02 \pm 0.001$ & 2.32 & $P>0.05$ (NS) & $\mathrm{H}_{0}$ accepted & 0.01 \\
\hline Chromium (mg/L) & $0.01-0.02$ & $0.02 \pm 0.001$ & 14.40 & $P>0.05$ (NS) & $\mathrm{H}_{0}$ accepted & 1.0 \\
\hline $\operatorname{Iron}(\mathrm{mg} / \mathrm{L})$ & $1.31-3.23$ & $2.59 \pm 0.89$ & 18.39 & $P<0.05(S)$ & $\mathrm{H}_{0}$ rejected & 0.05 \\
\hline Copper $(\mathrm{mg} / \mathrm{L})$ & $0.06-0.29$ & $0.19 \pm 0.11$ & 10.77 & $\mathrm{P}<0.05(\mathrm{~S})$ & $\mathrm{H}_{0}$ rejected & 0.1 \\
\hline
\end{tabular}

$\mathrm{S} . \mathrm{E}=$ Standard Error, $\mathrm{F}=$ Tabulated values, NESREA $=$ National Environmental Standards and Regulations Enforcement Agency, (NS) $=$ Not Significant, $(S)$ = Significant, $H_{0}=$ Null Hypothesis

season showed insignificant difference at $p>0.05$ (Table 3). $\mathrm{pH}$ ranged from 7.20 to 7.69 with a mean of $7.44 \pm$ 0.25 (Table 2). Within the four sampling stations, spatial variations of $\mathrm{pH}$ were significantly different $(p>0.05)$. Mean values of $\mathrm{pH}$ obtained in the wet season and dry season were $7.33 \pm 0.27$ and $7.55 \pm 0.39$ (Table 3 ), respectively. Seasonal variation between the wet and dry season showed insignificant difference at $p>0.05$ (Table 3). The values of dissolved oxygen recorded ranged from 3.07 to $3.79 \mathrm{mg} / \mathrm{L}$ with a mean of $3.35 \pm 0.33 \mathrm{mg} / \mathrm{L}$ (Table 2 ). Within the four sampling stations, spatial variations of dissolved oxygen showed insignificant difference $(p>0.05)$. Mean values of dissolved oxygen obtained in the wet and dry seasons were $3.66 \pm 0.51 \mathrm{mg} / \mathrm{L}$ and $3.03 \pm 0.30 \mathrm{mg} / \mathrm{L}$, respectively (Table 3 ). Seasonal variation between the wet and dry season showed significant difference at $p<0.05$ (Table 3). Biological oxygen demand (BOD) ranged from 1.53 to $2.80 \mathrm{mg} / \mathrm{L}$ with a mean of $2.73 \pm 0.21 \mathrm{mg} / \mathrm{L}$ (Table 2 ). The spatial variations of BOD within the sampling stations showed insignificant difference at $p>0.05$ (Table 2). Mean BOD concentrations obtained in the wet and dry seasons were $2.00 \pm 0.39 \mathrm{mg} / \mathrm{L}$ and $2.63 \pm 0.16 \mathrm{mg} / \mathrm{L}$, respectively (Table 3 ). Seasonal variation between the wet and dry season showed insignificant difference at $p>0.05$ (Table 3). The values of conductivity recorded ranged from 237.14 to $290.67 \mu \mathrm{S} / \mathrm{cm}$ with the mean value of $254.31 \pm$ $24.56 \mu \mathrm{S} / \mathrm{cm}$ (Table 2).
Within the four sampling stations, spatial variations of conductivity showed significant difference ( $p<0.05)$. Mean values of conductivity obtained in the dry and wet seasons were $250.87 \pm 34.15 \mu \mathrm{S} / \mathrm{cm}$ and $257.74 \pm 16.40 \mu \mathrm{S} / \mathrm{cm}$ (Table 3), respectively. Seasonal variation between the wet and dry season showed insignificant difference at $p>0.05$ (Table 3). The levels of TDS ranged from 414.63 to 700.14 $\mathrm{mg} / \mathrm{L}$ with the mean value of $528.63 \pm 124.56 \mathrm{mg} / \mathrm{L}$ (Table 2.). Within the four sampling stations, spatial variations of total dissolved solid shows significant difference $(p<0.05)$. Mean total dissolved solids obtained in the wet and dry seasons were $522.83 \pm 177.21 \mathrm{mg} / \mathrm{L}$ and $534.43 \pm 72.26$ $\mathrm{mg} / \mathrm{L}$, respectively (Table 3 ). Seasonal variation between the wet and dry season showed insignificant difference at $p>0.05$ (Table 3). The concentrations of TSS ranged from 1093.77 to $1376.06 \mathrm{mg} / \mathrm{L}$ with the mean value of $1205.35 \pm 125.57 \mathrm{mg} / \mathrm{L}$ (Table 2 ). Within the four sampling stations, spatial variations of TSS were significantly different $(p<0.05)$. Mean total dissolved solids obtained in the wet and dry seasons were $1191.80 \pm 117.23 \mathrm{mg} / \mathrm{L}$ and $1223.91 \pm 120.38 \mathrm{mg} / \mathrm{L}$, respectively (Table 3 ). Seasonal variation between the wet and dry season was not significantly different at $p>0.05$ (Table 3 ). The level of lead $(\mathrm{Pb})$ ranged from 0.00 to $0.01 \mathrm{mg} / \mathrm{L}$ with the mean value of $0.01 \pm 0.00 \mathrm{mg} / \mathrm{L}$ (Table 2 ). Within the four sampling stations, spatial variations of $\mathrm{Pb}$ showed significant difference $(p<0.05)$. Mean values of $\mathrm{Pb}$ obtained in the wet 
Table 3. Seasonal mean variation, standard error and F-values of physico-chemical parameters measured in the Calabar River for the wet and dry season

\begin{tabular}{|c|c|c|c|c|c|}
\hline Physico-chemical parameters & $\begin{array}{l}\text { Wet Season } \\
\text { Mean } \pm \text { S.E }\end{array}$ & $\begin{array}{l}\text { Dry Season } \\
\text { Mean } \pm S . E\end{array}$ & F-value & P-Probability & Inferences \\
\hline Surface water temperature $\left({ }^{\circ} \mathrm{C}\right)$ & $27.33 \pm 1.11$ & $26.71 \pm 0.70$ & 1.88 & $P>0.05$ (NS) & $\mathrm{H}_{0}$ accepted \\
\hline $\mathrm{pH}$ & $7.33 \pm 0.27$ & $7.55 \pm 0.39$ & 1.03 & $P>0.05(N S)$ & $\mathrm{H}_{0}$ accepted \\
\hline Dissolved oxygen $(\mathrm{mg} / \mathrm{L})$ & $3.66 \pm 0.51$ & $3.03 \pm 0.30$ & 18.02 & $\mathrm{P}<0.05(\mathrm{~S})$ & $\mathrm{H}_{0}$ rejected \\
\hline Biological oxygen demand $(\mathrm{mg} / \mathrm{L})$ & $2.00 \pm 0.39$ & $2.63 \pm 0.16$ & 4.24 & $\mathrm{P}>0.05$ (NS) & $\mathrm{H}_{0}$ accepted \\
\hline Conductivity $(\mu S / \mathrm{cm})$ & $257.74 \pm 16.40$ & $250.87 \pm 34.15$ & 0.41 & $\mathrm{P}>0.05$ (NS) & $\mathrm{H}_{0}$ accepted \\
\hline Total dissolved solids (mg/L) & $522.83 \pm 177.21$ & $534.43 \pm 72.26$ & 2.19 & $P>0.05(N S)$ & $\mathrm{H}_{0}$ accepted \\
\hline Total suspended solids (mg/L) & $1191.80 \pm 117.23$ & $1223.91 \pm 120.38$ & 4.41 & $\mathrm{P}>0.05$ (NS) & $\mathrm{H}_{0}$ accepted \\
\hline Lead (mg/L) & $0.01 \pm 0.01$ & $0.01 \pm 0.01$ & 0.00 & $P>0.05$ (NS) & $\mathrm{H}_{0}$ accepted \\
\hline Cadmium (mg/L) & $0.00 \pm 0.00$ & $0.00 \pm 0.00$ & 0.23 & $P>0.05$ (NS) & $\mathrm{H}_{0}$ accepted \\
\hline Chromium (mg/L) & $0.02 \pm 0.01$ & $0.01 \pm 0.00$ & 0.00 & $\mathrm{P}>0.05$ (NS) & $\mathrm{H}_{0}$ accepted \\
\hline $\operatorname{Iron}(\mathrm{mg} / \mathrm{L})$ & $1.67 \pm 0.74$ & $3.48 \pm 1.17$ & 16.76 & $\mathrm{P}<0.05(\mathrm{~S})$ & $\mathrm{H}_{0}$ rejected \\
\hline Copper $(\mathrm{mg} / \mathrm{L})$ & $0.22 \pm 0.15$ & $0.17 \pm 0.08$ & 0.96 & $\mathrm{P}>0.05$ (NS) & $\mathrm{H}_{0}$ accepted \\
\hline
\end{tabular}

S.E $=$ Standard Error, F = Tabulated values, $(N S)=$ Not Significant, $(S)=$ Significant, HO= Null Hypothesis

and dry seasons were $0.01 \pm 0.01 \mathrm{mg} / \mathrm{L}$ and $0.01 \pm 0.00$ $\mathrm{mg} / \mathrm{L}$, respectively (Table 3 ). Seasonal variation between the wet and dry season showed insignificantly different at p>0.05 (Table 3). Within the four sampling stations, spatial variations of cadmium showed insignificant difference $(p>0.05)$. Mean values of cadmium (Cd) obtained in the wet and dry seasons were also not detected (Table 3). Seasonal variation between the wet and dry season also showed insignificant difference at $\mathrm{p}>0.05$ (Table 3). The chromium $(\mathrm{Cr})$ level ranged from 0.01 to $0.02 \mathrm{mg} / \mathrm{L}$ with the mean value of $0.02 \pm 0.00 \mathrm{mg} / \mathrm{L}$ (Table 2 ). Within the four sampling stations, spatial variations in the levels of $\mathrm{Cr}$ showed insignificant difference at $\mathrm{p}>0.05$ during the study period. Mean Cr levels obtained in the wet and dry season were $0.02 \pm 0.01 \mathrm{mg} / \mathrm{L}$ and $0.01 \pm 0.00 \mathrm{mg} / \mathrm{L}$ (Table 3), respectively. Seasonal variation between the wet and dry season also showed insignificant difference at $p>0.05$ (Table 3). The levels of iron (Fe) ranged from 1.31 to $3.23 \mathrm{mg} / \mathrm{L}$ with the mean value of $2.59 \pm 0.89$ $\mathrm{mg} / \mathrm{L}$ (Table 2). Within the four sampling stations, spatial variations of Fe showed significant difference at $p<0.05$. Mean iron levels obtained in the wet and dry season were $1.67 \pm 0.74 \mathrm{mg} / \mathrm{L}$ and $3.48 \pm 1.17 \mathrm{mg} / \mathrm{L}$ (Table $3)$. Seasonal variation between the wet and dry season showed significant difference at $\mathrm{p}<0.05$ (Table 3). The copper (Cu) level ranged from 0.06 to $0.29 \mathrm{mg} / \mathrm{L}$ with the mean value of $0.19 \pm 0.11 \mathrm{mg} / \mathrm{L}$ (Table 2 ). Within the four sampling stations, spatial variations of copper showed significant difference $(p<0.05)$. Mean $\mathrm{Cu}$ levels obtained in the wet and dry seasons were $0.22 \pm 0.15$ $\mathrm{mg} / \mathrm{L}$ and $0.17 \pm 0.08 \mathrm{mg} / \mathrm{L}$ (Table 3), respectively. Seasonal variation between the wet and dry season showed insignificant difference at $p>0.05$ (Table 3).

\section{Ichthyofauna composition and abundance}

The relative abundance of various fish fauna taxa encountered at four different sampling stations is presented in Table 4, while the illustration in Fig. 2 shows the percentage composition of fish fauna phyla of the Calabar River. Twenty six (26) species were identified belonging to twenty two (22) families from the total of 17464 individuals collected across the stations. Clupeidae was the most abundant fish family with $13.61 \%$, followed by Cichlidae with $10.12 \%$, and Osteoglossidae was the least fish family with $0.59 \%$. Among the stations, Mugil cephalus was abundant only in Station 1 (13.40\%), while Clarias gariepinus was the most abundant in Station $2(11.60 \%)$ and Orechromis niloticus was the most abundant in Station $3(8.50 \%)$ and Station 4 (7.90\%). Heterotis niloticus was the least abundant (1.50\%); this species occurred only in Station 4. Mugilidae, Clariidae, Cichlidae, Gobiidae and Sciaenidae had the most abundant distribution for both wet and dry seasons, while Clupeidae, Bathyclupeidae, Carangidae and Sphyraenidae were low in the wet season but high in the dry season. There was no significant difference between the two seasons $(p>0.05)$. 
Table 4. Composition, absolute and relative abundance of fish fauna encountered in the Calabar River

\begin{tabular}{|c|c|c|c|c|c|c|c|c|c|c|}
\hline STATIONS/TAXA & S1 & $\%$ & S2 & $\%$ & S3 & $\%$ & S4 & $\%$ & Total & $\%$ \\
\hline \multicolumn{11}{|l|}{ CLAROTEIDAE } \\
\hline Chrysichthys nigrodigitatus & 198 & 8.7 & 181 & 6.2 & 253 & 5.1 & 345 & 4.9 & 997 & 5.7 \\
\hline \multicolumn{11}{|l|}{ BATHYCLUPEIDAE } \\
\hline Bathygobis soporator & 7 & 0.3 & 11 & 0.01 & 53 & 1.1 & 75 & 1.1 & 147 & 0.8 \\
\hline \multicolumn{11}{|l|}{ CYNOGLOSSIDAE } \\
\hline Cynoglossus senegalensis & 54 & 2.4 & 121 & 4.1 & 182 & 3.7 & 279 & 3.9 & 646 & 3.7 \\
\hline \multicolumn{11}{|l|}{ CARANGIDAE } \\
\hline Caranx hippos & 11 & 0.5 & 67 & 2.3 & 141 & 2.9 & 117 & 1.7 & 342 & 1.9 \\
\hline Caranx latus & 7 & 0.3 & 32 & 1.1 & 54 & 1.1 & 75 & 1.2 & 170 & 0.9 \\
\hline \multicolumn{11}{|l|}{ CLUPEIDAE } \\
\hline Ilisha africana & 102 & 4.5 & 179 & 6.2 & 192 & 3.9 & 216 & 3.1 & 703 & 4.0 \\
\hline Ethmalosa fimbriata & 187 & 8.3 & 191 & 6.5 & 300 & 6.1 & 325 & 4.6 & 1024 & 5.9 \\
\hline Pellonula sp. & 95 & 4.2 & 66 & 2.3 & 178 & 3.6 & 300 & 4.3 & 649 & 3.7 \\
\hline \multicolumn{11}{|l|}{ CLARIIDAE } \\
\hline Clarias gariepinus & 245 & 10.8 & 338 & 11.6 & 304 & 6.1 & 460 & 6.6 & 1375 & 7.9 \\
\hline \multicolumn{11}{|l|}{ CICHLIDAE } \\
\hline Orechromis niloticus & 168 & 7.4 & 247 & 8.5 & 421 & 8.5 & 553 & 7.9 & 1413 & 8.1 \\
\hline Chromidotilapia sp. & 18 & 0.8 & 27 & 0.9 & 98 & 1.9 & 208 & 2.9 & 355 & 2.0 \\
\hline \multicolumn{11}{|l|}{ CITHANNIDAE } \\
\hline Citharinus citherus & 114 & 5.0 & 158 & 5.4 & 241 & 4.9 & 312 & 4.5 & 840 & 4.8 \\
\hline \multicolumn{11}{|l|}{ ELOPIDAE } \\
\hline Elop lacerta & 2 & 0.1 & 23 & 0.8 & 45 & 0.9 & 33 & 0.6 & 105 & 0.6 \\
\hline \multicolumn{11}{|l|}{ ELEOTIDAE } \\
\hline Eleotris daganensis & 11 & 0.5 & 41 & 1.4 & 79 & 1.6 & 108 & 1.5 & 242 & 1.4 \\
\hline \multicolumn{11}{|l|}{ PERIOPHTHALMIDAE } \\
\hline Periophthalmus sp. & 94 & 4.1 & 133 & 4.6 & 419 & 8.5 & 598 & 8.5 & 1261 & 7.2 \\
\hline \multicolumn{11}{|l|}{ HEPSETIDAE } \\
\hline Hepstus odoe & 27 & 1.2 & 33 & 1.1 & 151 & 3.1 & 233 & 3.3 & 449 & 2.6 \\
\hline \multicolumn{11}{|l|}{ OSTEOGLOSSIDAE } \\
\hline Heterotis niloticus & 0 & 0 & 0 & 0 & 0 & 0 & 103 & 1.5 & 103 & 0.6 \\
\hline \multicolumn{11}{|l|}{ MASTACEMBLIDAE } \\
\hline Mastacemoelus loennbergii & 8 & 0.4 & 53 & 1.8 & 49 & 18.6 & 106 & 1.5 & 237 & 1.4 \\
\hline \multicolumn{11}{|l|}{ MONDACTYLIDAE } \\
\hline Monodactylus sebae & 20 & 0.9 & 25 & 0.9 & 96 & 1.9 & 163 & 2.3 & 308 & 1.7 \\
\hline \multicolumn{11}{|l|}{ MORMYRIDAE } \\
\hline Gnathonemus senegalensis & 148 & 6.5 & 169 & 8.7 & 264 & 5.3 & 350 & 4.9 & 952 & 5.5 \\
\hline \multicolumn{11}{|l|}{ MUGILIDAE } \\
\hline Mugil cephalus & 304 & 13.4 & 213 & 7.9 & 373 & 7.5 & 445 & 6.3 & 1363 & 7.8 \\
\hline \multicolumn{11}{|l|}{ MOCHOKIDAE } \\
\hline Synodontis eupterus & 7 & 0.3 & 49 & 1.7 & 137 & 2.8 & 282 & 4.0 & 480 & 2.8 \\
\hline POLYNEMIDAE & & & & & & & & & & \\
\hline Polydactyl us quadrafilis & 143 & 6.3 & 172 & 5.9 & 265 & 5.4 & 395 & 5.6 & 993 & 5.7 \\
\hline SCIAENIDAE & & & & & & & & & & \\
\hline Pseudolithus elongatus & 186 & 8.2 & 205 & 7.0 & 373 & 7.5 & 475 & 6.8 & 1262 & 7.2 \\
\hline SCHILBEIDAE & & & & & & & & & & \\
\hline Schilbe mystus & 68 & 2.9 & 122 & 4.2 & 178 & 3.6 & 254 & 3.6 & 633 & 3.6 \\
\hline SPHYRAENIDAE & & & & & & & & & & \\
\hline Sphyraena barracuda & 48 & 2.1 & 67 & 2.3 & 104 & 38.9 & 209 & 2.9 & 471 & 2.7 \\
\hline Total number of species & 25 & & 25 & & 25 & & 26 & & 101 & \\
\hline Total number of individuals & 2272 & 100 & 2923 & 100 & 4950 & 100 & 7019 & 100 & 17464 & 100 \\
\hline
\end{tabular}




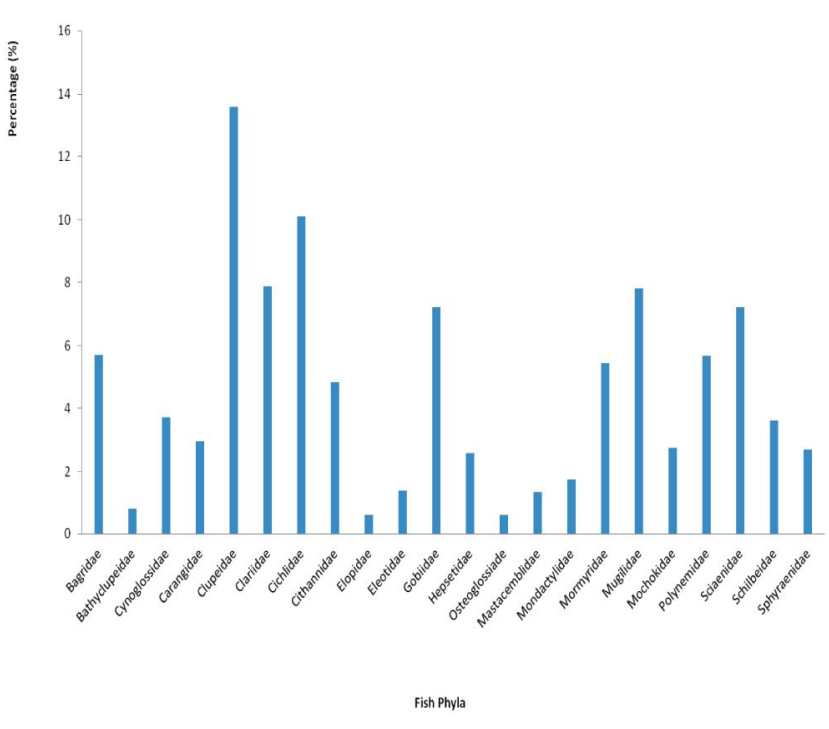

Fig 2. Composition of fish families in the Calabar River (Nigeria) during the study period

\section{Diversity indices of ichthyofauna}

Summary of the diversity and dominance indices calculated during the study for the four sampling stations is presented in Table 5. Species richness calculated as Margalef's index (d) was least in Station 3 (2.821), which is the second downstream station, while Station 1 accounted for the highest diversity (3.105). Shannon diversity index $(H)$ in Station 1 accounted for the lowest diversity (2.770), while Station 4 accounted for the highest diversity (3.095). Equitability was least in Station 1 (0.8606) and highest in Station 4 (0.9498). The four stations had low dominance levels with no significant difference in index values $(p>0.05)$.

\section{Correlation between physico-chemical parameters and ichthyofauna assemblages}

Correlation co-efficient ( $r$ ) values for physico-chemical parameters and fish fauna abundance are presented in Table 6. Clarias gariepinus, Mastacemoelus loennbergii significantly correlated positively with surface water temperature $(r=0.96 ; r=0.97)$, Bathygobis soparator, Orechromis niloticus, Chromidotilapia sp., Citharinus citherus, Periophthalmus sp., Hepstus odoe, Monodactylus sebae, Synodontis eupterus, Pseudodolithus elongatus, Sphyraena barracuda significantly correlated positively with DO $(r=$ $0.98 ; r=0.96 ; r=0.99 ; r=0.96 ; r=0.98 ; r=0.99 ; r=0.98$; $r=0.98 ; r=0.99$ and $r=0.97)$, respectively. Chrysichthyes nigrodigitatus, Heterotis niloticus and Sphyraena barracuda significantly correlated positively with conductivity ( $r=0.96$; $r=0.99$ and $r=0.96)$, Bathygobis soparator significantly correlated positively with chromium $(r=0.96)$ and Mugil cephalus significantly correlated positively with copper $(r=$ 0.96 ) at $\mathrm{p}<0.05$.

\section{DISCUSSION}

\section{Physico-chemical parameters}

The most common physical assessment of water quality is the temperature. In fact, no other single factor has such an intense influence and direct, as well as indirect, effect on biota of an ecosystem like temperature (Fauzia and Khan, 2013). During the study, the result showed that the mean surface water temperature fell within the normal temperature which ranged from $20-40^{\circ} \mathrm{C}$ as recommended by the National Environmental Standards and Regulations Enforcement Agency, indicating that the river is thermally unpolluted. Andem et al. (2013) reported similar temperature

Table 5. Diversity indices of fish fauna of the Calabar River

\begin{tabular}{lcccc}
\hline \hline Biotic Indices/Stations & S1 & S2 & S3 & S4 \\
\hline Simpson's Index (D) & 0.0745 & 0.0607 & 0.0537 & 0.0504 \\
Shannon Index (H) & 2.770 & 2.954 & 3.043 & 3.095 \\
Margalef's Index (d) & 3.105 & 3.007 & 2.821 & 2.823 \\
Equitability (E) & 0.8606 & 0.9178 & 0.9454 & $\mathbf{2 5}$ \\
Taxa & $\mathbf{2 5}$ & $\mathbf{2 5}$ & $\mathbf{2 5}$ & $\mathbf{2 6}$ \\
Individual & $\mathbf{2 2 7 2}$ & $\mathbf{2 9 2 3}$ & $\mathbf{7 6 1 9}$ \\
\hline \hline
\end{tabular}

S1 $($ Station one) $=$ Tinapa Resort Beach, S2 (Station two) = Addax Petroleum Company, S3 (Station three) = Itiat Ekpe Beach, S4 (Station four) $=$ Nsidung Beach 
in the intertidal region of the Calabar River; this could be attributed to the fact that only degraded organic and inorganic matter contained in the effluents was discharged into the river. Similar result was also observed by Yakub (2010) who reported surface water temperature in the lower Ogun River; this resulted from the fact that degraded organic matter contained in the effluent was discharged into the river. The spatial variations in the physico-chemical parameters indicate the influence of season on the physicochemical hydrology of the Calabar River. Adebisi (1981), cited by Grover and Chrzanowski (2006), reported that the rainfall pattern is an important climatic factor governing the physico-chemical dynamics of water bodies. The $\mathrm{pH}$ of the water was mostly alkaline throughout the course of the study. The result of this study shows that the $\mathrm{pH}$ range was within the recommended range (6.0-9.0), as

Table 6. Correlation co-efficient ( $r$ ) between some environmental variables and ichthyofauna abundance of the Calabar River

\begin{tabular}{|c|c|c|c|c|c|c|c|c|c|c|c|c|}
\hline $\begin{array}{l}\text { Physico-chemical } \\
\text { Parameter/ } \\
\text { Fish fauna }\end{array}$ & $\begin{array}{l}\text { Surface } \\
\text { water } \\
\text { temp }\left({ }^{\circ} \mathrm{C}\right)\end{array}$ & pH & DO & BOD & $\begin{array}{c}\text { Conductivity } \\
\mu S / \mathrm{cm}\end{array}$ & TDS & TSS & Lead & Cadmium & Chromium & Iron & Copper \\
\hline $\begin{array}{l}\text { Chrysichthyes } \\
\text { nigrodigitatus }\end{array}$ & 0.67 & -0.51 & 1.00 & 0.65 & $0.96 *$ & 0.85 & 0.93 & -0.43 & 0.00 & 0.86 & -0.82 & 0.86 \\
\hline $\begin{array}{l}\text { Bathygobis } \\
\text { soparator }\end{array}$ & 0.69 & -0.25 & $0.98 *$ & 0.50 & 0.85 & 0.67 & 0.79 & -0.16 & 0.00 & $0.96 *$ & -0.63 & 0.90 \\
\hline $\begin{array}{l}\text { Cynoglossus } \\
\text { senegalensis }\end{array}$ & 0.87 & -0.17 & 0.94 & 0.31 & 0.86 & 0.63 & 0.74 & -0.09 & 0.00 & 0.86 & -0.65 & 0.73 \\
\hline Caranx hippos & 0.64 & 0.30 & 0.71 & 0.03 & 0.45 & 0.16 & 0.33 & 0.40 & 0.00 & 0.90 & -0.13 & 0.71 \\
\hline Caranx latus & 0.86 & -0.04 & 0.91 & 0.23 & 0.79 & 0.53 & 0.65 & 0.04 & 0.00 & 0.89 & -0.54 & 0.73 \\
\hline IIisha africana & 0.92 & 0.25 & 0.72 & -0.10 & 0.59 & 0.27 & 0.40 & 0.31 & 0.00 & 0.74 & -0.33 & 0.50 \\
\hline Ethmalosa fimbriata & 0.62 & -0.19 & 0.94 & 0.49 & 0.77 & 0.59 & 0.73 & -0.08 & 0.00 & 0.99 & -0.53 & 0.93 \\
\hline Clarias gariepinus & $0.96 *$ & -0.23 & 0.81 & 0.18 & 0.86 & 0.66 & 0.71 & -0.20 & 0.00 & 0.58 & -0.75 & 0.43 \\
\hline Orechromis niloticus & 0.79 & -0.18 & $0.96 *$ & 0.39 & 0.84 & 0.63 & 0.75 & -0.09 & 0.00 & 0.93 & -0.62 & 0.83 \\
\hline Chromidotilapia sp. & 0.76 & -0.41 & $0.99 *$ & 0.54 & 0.95 & 0.80 & 0.89 & -0.33 & 0.00 & 0.86 & -0.80 & 0.81 \\
\hline Citharinus citherus & 0.80 & -0.17 & $0.96 *$ & 0.38 & 0.85 & 0.63 & 0.75 & -0.09 & 0.00 & 0.92 & -0.62 & 0.81 \\
\hline Elop lacerta & 0.61 & 0.43 & 0.60 & -0.09 & 0.33 & 0.02 & 0.20 & 0.52 & 0.00 & 0.84 & 0.00 & 0.62 \\
\hline Eleotris daganensis & 0.83 & -0.08 & 0.93 & 0.29 & 0.80 & 0.55 & 0.68 & 0.01 & 0.00 & 0.92 & -0.56 & 0.78 \\
\hline Periophthalmus sp. & 0.71 & -0.26 & $0.98 *$ & 0.49 & 0.86 & 0.68 & 0.80 & -0.17 & 0.00 & 0.95 & -0.65 & 0.88 \\
\hline Hepstus odoe & 0.70 & -0.31 & $0.99 *$ & 0.54 & 0.88 & 0.72 & 0.83 & -0.22 & 0.00 & 0.94 & -0.68 & 0.89 \\
\hline Heterotis niloticus & 0.75 & -0.61 & 0.88 & 0.56 & $0.99 *$ & 0.92 & 0.93 & -0.58 & 0.00 & 0.58 & -0.96 & 0.57 \\
\hline $\begin{array}{l}\text { Mastacemoelus } \\
\text { loennbergii }\end{array}$ & $0.97 *$ & -0.13 & 0.84 & 0.15 & 0.84 & 0.60 & 0.67 & -0.09 & 0.00 & 0.68 & -0.68 & 0.51 \\
\hline Monodactylus sebae & 0.78 & -0.25 & $0.98 *$ & 0.44 & 0.88 & 0.69 & 0.80 & -0.16 & 0.00 & 0.92 & -0.67 & 0.83 \\
\hline $\begin{array}{l}\text { Gnathonemus } \\
\text { senegalensis }\end{array}$ & 0.75 & -0.29 & 0.99 & 0.49 & 0.89 & 0.71 & 0.82 & -0.20 & 0.00 & 0.92 & -0.69 & 0.85 \\
\hline Mugil cephalus & 0.38 & -0.57 & 0.93 & 0.82 & 0.85 & 0.81 & 0.90 & -0.48 & 0.00 & 0.88 & -0.72 & $0.96 *$ \\
\hline Synodontis eupterus & 0.81 & -0.32 & $0.98 *$ & 0.46 & 0.93 & 0.75 & 0.84 & -0.24 & 0.00 & 0.86 & -0.75 & 0.78 \\
\hline $\begin{array}{l}\text { Polydactylus } \\
\text { quadrafilus }\end{array}$ & 0.79 & -0.34 & $0.99 *$ & 0.49 & 0.93 & 0.75 & 0.85 & -0.26 & 0.00 & 0.88 & -0.75 & 0.81 \\
\hline $\begin{array}{l}\text { Pseudolithus } \\
\text { elongatus }\end{array}$ & 0.71 & -0.27 & $0.98 *$ & 0.50 & 0.86 & 0.68 & 0.80 & -0.17 & 0.00 & 0.95 & -0.65 & 0.89 \\
\hline Schilbe mystus & 0.86 & -0.16 & 0.94 & 0.32 & 0.85 & 0.63 & 0.74 & -0.08 & 0.00 & 0.88 & -0.64 & 0.75 \\
\hline $\begin{array}{l}\text { Sphyraena } \\
\text { barracuda }\end{array}$ & 0.82 & -0.41 & $0.97 *$ & 0.49 & $0.96 *$ & 0.81 & 0.88 & -0.35 & 0.00 & 0.80 & -0.83 & 0.74 \\
\hline
\end{tabular}

* Correlation is significant at $p<0.05$ 
suitable for aquatic life (NESREA, 2011). Similar alkaline pH condition was reported in the intertidal region of the Calabar River (Andem et al., 2013). The spatial variation in $\mathrm{pH}$ was significant. This is an indication that various anthropogenic disturbances significantly alter the $\mathrm{pH}$ along the river. The dissolved oxygen concentration in the Calabar River was low and below the acceptable limit $(5.0 \mathrm{mg} / \mathrm{L})$ for fish survival by the National Environmental Standards and Regulations Enforcement Agency. High organic content from human faeces and domestic wastes from the intertidal region of the Calabar River may be responsible for low dissolved oxygen. Similar reports on organic pollution with marked reduction in dissolved oxygen level include that of Andem et al. (2013) in the intertidal region of the Calabar River caused by organic rich effluent from domestic and agricultural activities, and Lawson (2011) in the Lagos Lagoon caused by human sewage and municipal waste discharge.

The higher level of dissolved oxygen in the dry season might be attributed to possible increase in photosynthetic activities of the river, while lower dissolved oxygen in the wet season could be explained by the decrease in photoperiod, photosynthetic activities and increase in turbulence and turbidity of the river, and also by some chemical, biological oxidation processes, as well as increase in organic load from the river runoff. Similar observation was also made by Mane (2002) in the Manar River near Degloor District, India. The mean BOD was less than $4 \mathrm{mg} / \mathrm{L}$, which is suitable for aquatic life as recommended by the National Environmental Standards and Regulations Enforcement Agency. Since the BOD range in the present study did not exceed the limit (4.0 $\mathrm{mg} / \mathrm{L})$, it does not pose a threat to the aquatic life. Higher BOD of $5.0 \mathrm{mg} / \mathrm{L}$ recorded in Station 4 might be attributed to the different organic waste from human sewage and waste water from residential areas discharged into the river which brings Station 4 into the brink of pollution. The higher BOD level in the wet season could be the effect of runoff water from heavy rainfall which carries wastes and deposit in the river, while lower values in the dry season could be due to reduction in the amount of runoff water discharge into the river (Abowei and Sikoki, 2005; Andem et al., 2012). Conductivity level below $50 \mu \mathrm{S} / \mathrm{cm}$ is expected to be low; between $50-600 \mu \mathrm{S} / \mathrm{cm}$ fall within the medium class, while above $600 \mu \mathrm{S} / \mathrm{cm}$ fall in the high class according to the National Environmental Standards and Regulations Enforcement Agency. In this study, conductivity range between 237.14 $\mu \mathrm{S} / \mathrm{cm}-290.67 \mu \mathrm{S} / \mathrm{cm}$, which falls within the medium class, indicated moderate pollution (NESREA, 2011). In the past two decades, research done on the physico-chemistry in many Nigerian inland water bodies showed that conductivity levels were less than $500 \mu \mathrm{S} / \mathrm{cm}$ during the dry season and less than $100 \mu \mathrm{S} / \mathrm{cm}$ during the wet season (Egborge, 1992). Similar findings were also observed by Andem et al. (2012) in the Ona River. The conductivity of this study followed a similar trend, increasing in the wet season and decreasing in the dry season. Similar work by Oben (2000) showed increase in conductivity level in the wet season, which could be attributed to more mineralization of organic matter and the concentration of ions could result to evaporation, while the decrease in conductivity values during the dry season may be a result of decomposition of allochthonous organic materials discharged into the river. Similar findings were recorded by Okayi (2003) in the River Benue. The author also suggested that the increase in conductivity values during the rainy season may be due to dilution by rainwater. He also reported that in the wet season allochthonous materials brought in by streams draining from catchments area and then discharged into the reservoir may play a major role in their limnology. Low conductivity levels recorded for the dry season may be a result of utilized allochthonous materials by the phytoplanktonic organisms of the river. High conductivity values have been reported to be indicative of an increase in the amount of polluting particles (Oben, 2000). Range of TDS and TSS obtained in this study were high and beyond acceptable limit for drinking water and survival of aquatic life as recommended by the National Environmental Standards and Regulations Enforcement Agency. High levels of total dissolved solids and total suspended solids observed in this study could be a result of regular discharge of wastes from domestic and industrial sources. The continuous deposition of these wastes into the river could impede the free flow of the river. Long term deposition of materials in the river could also result in flooding, particularly during heavy rainfall, which could have both economic and ecological implications (Andem et al., 2012). Metal concentrations in the environment are controlled by various processes such as particulate surface adsorption and micronutrient cycle (Lawson, 2011). The concentrations of some heavy metals in water such as lead, chromium and copper in this study were below permissible limit for drinking water and survival of aquatic life by the National Environmental Standards and Regulations Enforcement Agency, except for cadmium and iron which were above the recommended standard. This could be a result of anthropogenic wastes from household and dump sites containing these materials (such as batteries and insecticides found in dump sites around the river) and because of its closeness to a highly industrialized area. Heavy metal detected was higher during the dry season than rainy season; this may be due to dilution from heavy rainfalls during the rainy season. Similar findings were also made by Kar et al. (2008) from the River Ganga.

\section{Ichthyofauna assemblages}

The results indicate that fish fauna diversity of the Calabar River was generally very high. The relative fish abundance compare favourably with similar reports on streams in 
southern Nigeria (Imefon, 2012). However, Udoidiong and King (2000) investigate the relative abundance of fish fauna in two second-order streams of Akwa Ibom State and these are as follows: authors reported that the Esedeke have 25 fish species belonging to 23 genera representing 16 families and the lba-Oku have 18 fish species belonging to 17 genera representing 13 families. Similar findings were observed by Onuoha et al. (2010); authors recorded 26 fish species belonging to 20 families during their study in the Ntak Inyang Stream. The aforementioned studies are very similar to the present study which recorded 26 species belonging to 26 genera representing 22 families. Sikoki et al. (2008) investigated the fish fauna of the Onulyi ukwu stream in southeastern Nigeria. In their study, they recorded 17 fish species belonging to 15 genera and 11 families. The results of the present study are different from that of Udoidiong and King (2000). This could be due to differences in the research period and sampling frequency. In this study, Mugilidae, Clariidae, Gobiidae, Sciaenidae, Clupeidae and Cichlidae were the most abundant and dominant groups. Studies indicated that the major causes of declining fish catches from the river are increased fishing pressure and habitat destruction (Emmanuel and Onyema, 2007). However, distribution and abundance of fish in tropical water bodies have been variously attributed to several factors, particularly depth (Idodo-Umeh, 2003). The dominance of the members of the family Cichlidae in the Calabar River, attributed to the fact that they reproduce very fast, means that they are prolific breeders and this confirms that they were under uncontrolled conditions. Similar observation was made by Obasohan and Oronsaye (2006) in Ikpoba Reservoir in Edo State. A higher abundance of the fish species during the dry season than in the rainy season could be attributed to the fact that the water level was low which causes fishes to concentrate more in the environment. Ayoola and Kuton (2009) recorded higher abundance of fish species at low levels of water in the Lagos Lagoon during the dry season. Higher ShannonWeiner index $(\mathrm{H})$ and Margalef's index (d) were recorded in the river. The low value of dominant fish species could be caused by flood which might lead to migration of some fish in the river. Flood on aquatic ecosystem has been known to have a negative effect on the distribution of the resident organism (Ogbeibu and Oribhabor, 2002). The distribution and abundance of fish fauna, as the results show, were also affected by the physico-chemical qualities such as surface water temperature, DO, conductivity, high concentration of chromium and copper in the water. These parameters positively correlated significantly with fish species including Clarias gariepinus, Mastacemoelus loennbergii, Bathygobis soparator, Orechromis niloticus, Chromidotilapia sp., Citharinus citherus, Periophthalmus sp., Hepsetus odoe, Monodactylus sebae, Synodontis eupterus, Pseudodolithus elongatus, Sphyraena barracuda, Chrysichthyes nigrodigitatus, Heterotis niloticus and Mugil cephalus. This is an indication of the ability of organisms to survive and migrate to more favourable conditions or die under unfavourable environmental conditions as was also reported by Tejerina-Garro and De Merrona (2010). Similar trends in the correlation between effect of water quality and the distribution of fish fauna have been reported by Othman et al. (2001). The weak correlation between some of the fish fauna and water quality parameters could be attributed to the variation in mesh size and gear use by fishermen, which might have greatly influenced the species composition and abundance in this study.

\section{CONCLUSION}

Ecological relevance of the measured physico-chemical parameters was assessed by comparing the degree of correlation of fish fauna diversity. The result revealed that the fish fauna showed fairly good relation with physicochemical attributes and the value of data obtained reflected the conditions existing in the river in terms of the quality and quantity of the biota. Considering the temperature, $\mathrm{pH}$ and dissolved oxygen content of the water, it can be said the river is moderately unpolluted. However, the level of conductivity, biological oxygen demand and total dissolved solids are an indication of pollution of the river in spite of the factors. In this study, fish fauna diversity across the sampling stations remains high, suggesting that the water quality of the Calabar River is good and supports diverse, well stable and balanced fish assemblages of the river. It also provides a healthy environment for growth and survival of biological communities, but this does not mean that the river is free from pollution. The ichthyofauna assemblage such as abundance and composition was high. This could be due to a low water level and depth of the river. The presence of certain fish fauna in polluted and non-polluted parts of the river indicates that they could be used as potential bioindicators in assessment and biomonitoring of the river. The methods used in identifying fish diversity in the river proved their applicability for future studies in other regions of the country and the world at large.

\section{Sažetak}

\section{VARIJABILNOST OKOLIŠNIH PARAMETARA I EKOLOŠKA DISTRIBUCIJA IHTIOFAUNE U JUGOISTOČNOM PRIOBALNOM PODRUČJU RIJEKE KALABAR, NIGERIJA}

Studije o varijabilnosti okoliša i ekološkoj distribuciji intiofaune provedene su u rijeci Kalabar. Uzorkovane su 
površinske vode i ihtiofauna s ciljem da se dobiju osnovni podaci o postojećem stanju rijeke Kalabar, te buduća stanja rijeke. Sezonske varijacije pokazuju značajne razlike $\mathrm{u}$ temperaturi površinske vode, pH-u, DO-u, BPK-u, vodljivosti, TDS-u i TSS-u između uzorkovanih postaja, te neznatne razlike u sadržaju teških metala poput kadmija, kroma, željeza i bakra. Identificirano je dvadeset i šest ribljih vrsta koje spadaju u dvadeset dvije obitelji. Mugilidae, Clariidae, Cichlidae, Gobiidae i Sciaenidae su bile najviše zastupljene i za vrijeme kišne i suhe sezone, dok su Clupeidae, Bathyclupeidae, Carangidae i Sphyraenidae bile manje zastupljene $u$ kišnoj sezoni, ali visoko zastupljene $u$ suhoj sezoni. Krom, bakar, površinska temperatura vode $i$ DO značajno su korelirali s prisutnošču vrsta $E$. fimbriata, $B$. soporator, M. sebae, C. gariepinus, M. loennbergii, C. guentheri i $P$. babarus. Ukupna vrijednost biotičkih indeksa raznolikosti se kretala u rasponu od 0,0504-0,0745 za Simpsonov indeks, 2,770-3,095 za Shannonov indeks, 2,821-3,105 za Margalef indeks i 0,8606-0,9498 za nepristranost. Međutim, prisutnost određenih ribljih vrsta u zagađenim i nezagađenim dijelovima rijeke ukazuje na to da bi se mogle koristiti kao mogući bioindikatori u procjeni i biomonitoringu rijeke. Metode koje se koriste u određivanju raznolikosti riba potvrdile su da se mogu primjenjivati i u budučim istraživanjima.

Ključne riječi: ekološka distribucija, intiofauna, biotički indeks, zagađenje

\section{REFERENCES}

Abowei, J. F. N., Sikoki, F. D. (2005): Water Pollution: Management and Control. Double Trust Publishers, Port Harcourt, Nigeria, pp. 254.

Adebisi, A. A. (1981): The Physical and Chemical Hydrology of a Tropical Seasonal River, Upper Ogun River. Hydrobiologia, 79, 157-165.

Adesulu, E. A., Sydenham, D. H. (2007): The Freshwater Fishes and Fisheries of Nigeria. Macmillan Nigeria Publishers Limited, Yaba, Lagos, pp. 33-397.

Alexandre, C.V., Esteves, K. E, de Moura e Mello, M. A. (2010): Analysis of Fish Communities along a Rural-Urban Gradient in a Neotropical Stream (Piracicaba River Basin, São Paulo, Brazil). Hydrobiologia, 641, 97-114.

Andem, A. B., Okorafor, K. A., Eyo, V. O., Ekpo, P. B. (2013): Ecological Impact Assessment and Limnological Characterization in the Intertidal Region of Calabar River Using Benthic Macroinvertebrates as Bioindicator Organisms. International Journal of Fisheries and Aquatic Studies, 1, 2, 8-14.

Andem, A. B., Udofia, U., Okorafor, K. A., Okete, J. A., Ugwumba, A.A. (2012): A Study on Some Physical and Chemical Characteristics of Ona River, Apata, Ibadan South-west, Oyo State, Nigeria. European Journal of
Zoological Research, 1, 2, 37-46.

APHA/AWWA and WEF. (1995): Standard Methods for the Examination of Water and Waste Water. $20^{\text {th }}$ Edition. Washington DC, pp. 1132-1145.

Ayoola, S. O., Kuton, M. P. (2009): Seasonal Variations in Fish Abundance and Physico-chemical Parameters of Lagos Lagoon Nigeria. African Journal of Environmental Science and Technology, 3, 5, 149-156.

Banks, J.W., Holden, M. J., Mc-Connel, R.M. (1965): Fishery Report. In: White E (Ed). The First Scientific Report of the Kainji Biological Research Team. University of Ile-Ife, Nigeria, pp. 88

Baran, E., Jutagate, T. (2010): Would Barriers to Migration have the same Effect on all Fish species? In: Dugan, P. and Barlow, C. (eds.) Dams as Barriers to Fish Migration in the Mekong, and Possibilities for Mitigation, MRC Technical Paper, Mekong River Commission, Vientiane, p. 35-42.

Cross River National Park (CRNP) (2010): Important Bird Areas Factsheet. Oban Division. Bird Life International, p. 9.

Dudgeon, D. (2000): The Ecology of Tropical Asian Rivers and Streams in Relation to Biodiversity Conservation. Annual Review of Ecology and Systematic, 31, 239-263.

Egborge, A.B.M. (1992): Problems of Aquatic Resources Conservation. A Case Study of Nigerian Fishes. In Proceedings of the National Conference on Aquatic Resources, Calabar. 11-14th May, 1992, pp. 27.

Emmanuel, B. E., Onyema, I. C. (2007): The plankton and Fishes of Tropical Creek in South western Nigeria. Tropical Journal of Fisheries and Aquatic Sciences, 7, 105-114.

Eze, E. B., Effiong, J. (2010): Morphometric Parameters of the Calabar River Basin: Implication for Hydrologic Processes. Journal of Geography and Geology, 2 (1), 19161920.

Farombi, E. O., Adelowo, O. A and Ajimoko, Y. R. (2007): Biomakers of Oxidative Stress and Heavy metal levels as Indicators of Environmental Pollution in African catfish (Clarias gariepinus) from Nigerian Ogun River. International Journal of Environmental Resources and Public Health, 4, 2, 158-165

Fauzia, I., Khan, A. (2013): Diversity Pattern of Macro-zoobenthos and their Relation with Qualitative Characteristics of River Yamuna in Doon Valley Uttarakhand. AmericanEurasian Journal of Toxicological Sciences, 5, 1, 20-29.

Ferreira, F. C., Petrere, M. (2009): The Fish Zonation of the Itanhae River Basin in the Atlantic Forest of Southeast Brazil. Hydrobiologia, 636, 11-34

Food and Agriculture Organization (FAO) (2001): Methods of Collection and Analysing Size and Age Data for Fish Stock Assessment. FAO Fish Circular, 736, 1-100

Grover, J. P., Chrzanowski, T. H. (2006): Seasonal Dynamics of Phytoplankton in Two Warm Temperate Reservoir Association of Taxonomic Composition with Temperature. Journal of Plankton Research, 28, 1, 1-17. 
Gullard, J. A. (1980): General Concept of sampling fish. Fisheries Department, FAO. Rome, pp. 7-12.

He, Y., Wang, J., Lek-Ang, S., Lek, S. (2010): Predicting Assemblages and Species Richness of Endemic Fish in the Upper Yangtze River. Science of the Total Environment, 408, 4211-4220.

Idodo-Umeh, G. (1987): Studies on the fish community of River Ase, Bendel State with special Emphasis on the Food and Feeding Habits of Citharinidae, Bagridae, Schilbidae and Mokochidae, PhD Thesis, University of Benin, Benin City. p. 412.

Idodo-Umeh, G. (2003): Fresh Water Fishes of Nigeria Taxonomy, Ecological Notes, Diet and Utilization. Idodo Umeh Publishers Limited, p. 7-221.

Imefon, U. U. (2013): Taxonomic Composition, Diversity and Abundance of the Ichthyofaunal Assemblage of Iba-Oku Stream, Ikpa River, Nigeria. International Journal of Zoological Research, 8, 2, 71-80.

Ita, E.O. (1978): An Analysis of Fish Distribution in Kainji Lake, Nigeria. Hydrobiology, 58, 3, 235-244.

Ita, E.O. (1993): Inland Fishery Resources of Nigeria. F.A.O. CIFA Occasional Paper No. 20, pp. 120.

Kar, D., Sur, P., Mandal, S. K., Saha, T., Kole, R. K. (2008): Assessment of Heavy metal pollution in surface water from River Ganga in West Bengal. International Journal of Environmental Science and Technology, 5, 1, 119-124.

Kimmel, W.G., Argent, D. G. (2010): Stream Fish Community Responses to a Gradient of Specific Conductance. Water Air and Soil Pollution, 206, 49-56.

Kusemiju, K., Olaniyan, C.I.O. (1997): The Food and Feeding Habits of the Catfish: Chrysichthys walker (Gunther), Chrysichthys filamentosus (Boulenger) and Chrysichthys nigrodigitatus (Lacepedae) in the Lekki Lagoon, Nigerian Journal of Fish Biology, 10, 105-112.

Lawson, E. O. (2011): Physico-chemical Parameters and Heavy Metal Content of Water from the Mangrove Swamps of Lagos Lagoon, Lagos, Nigeria. Advances in Biological Research, 5, 1, 8-21.

Mane, M. E. (2002): The Study of Hydrobiology of Manar River Near Degloor District, Nanded. Ph.D. Thesis, S.R.T.M. University, Nanded, Maharashtra India, pp. 198.

Mims, M.C., Olden, J. D., Shattuck, Z. R., Poff, N. L. (2010): Life History Trait Diversity of Native Freshwater Fishes in North America. Ecology of Freshwater Fish, 19, 390-400.

National Environmental Standards and Regulations Enforcement Agency (NESREA) (2011): National Environmental (Surface and Groundwater Quality), p. 693-72 7.

Nwadiaro, C. S. (1984): The Longitudinal Distribution of Macro-invertebrates and Fish in a lower Niger Delta River (River Sombrerio) in Nigeria. Hydrobiology Bulletin, 18, $13-40$.
Obasohan, E. E., Oronsaye, J. A. (2006): Biodiversity and Sustainability of Freshwater Fishes of Nigeria, FISON Proceeding, pp. 230-237.

Oben, B. O. (2000): Limnological Assessment of the Impact of Agricultural and Domestic Effluents in Three Manmade Lakes in Ibadan, Nigeria. PhD Thesis, University of Ibadan, Ibadan, pp. 176

Ogbeibu, A. E. (2005): Biostatistics: A Practical Approach to Research Data Handling. Mindex Publishing Company Ltd. Nigeria, p.p $153-162$.

Ogbeibu, A. E., Oribhabor, B. J. (2002): Ecological Impact of River Impoundment Using Benthic Macro-invertebrates as Indicator. Water Research, 36, 242 7-2436.

Okayi, R. G. (2003): Effect of Effluent Discharge on Water Quality, Distribution and Abundance of Plankton and Fish Species of River Benue. Ph.D Thesis. University of Ibadan, Ibadan, pp. 198.

Onuoha, G. C., Ekpo, I. E., Chude, L. a., Isangedighi, I. A. (2010): Composite Preliminary Ichthyofaunal Survey of Ntak Inyang Stream, Ikpa River, Nigeria. Nigeria Journal of Agricultural and Food Environment, 6, 83-89.

Orrego, R., Adams, S.M., Barra, R., Chiang, G., Gavilan, J. F. (2009): Patterns of Fish Community Composition along a River Affected by Agricultural and Urban Disturbance in South-central Chile. Hydrobiologia, 620, 35-46.

Othman, M. R., Samat, A., Hoo, L. S. (2001): Effect of Water Quality to Fish Abundance and Chlorophyll a (Selected Aquatic Organisms) in Labu River System, Malaysia. Journal of Biological Science, 1, 1178-1182.

Penczak, T. (2002): Threatened Obligatory Riverine Fishes in Human Modified Polish Rivers. Ecology of Fresh Water Fish, 9, 109-117.

Reed, W., Burschard, J., Hopson, A.J., Jenness, J., Yaro, I. (2000): Fish and Fisheries of Northern Nigeria. Ministry of Agriculture, Northern Nigeria, pp. 226.

Sikoki, F.D., Zabbey, N., Anyanwu, I. N. (2008): Fish Assemblages of Onu-lyi-Ukwu Stream in Southeastern Nigeria. Tropical Freshwater Biology, 17, 41-51.

Tejerina-Garro, F. L., De Merrona, B. (2010): Flow Seasonality and Fish Assemblage in Tropical River, French Guiana, South America. Neo-tropical Ichthyology, 8, 1-16.

Udoidiong, O. M., King, R. P. (2000): Ichthyofauna Assemblages of Some Nigerian Rainforest streams. Journal Aquatic Science, 15, 1-8.

Welman, J. B. (2003): Preliminary Survey of the Fresh Water Fisheries of Nigeria. Government Printer, Lagos, Nigeria, pp. 88.

Yakub, A. S. (2010): Physico-chemical Parameters, Macroinvertebrates and Fish fauna of lower Ogun River at Ishasi-Olofin, Ogun State. Ph.D Thesis, Department of Zoology, University of Ibadan, Ibadan, pp. 162. 